\title{
Turkish Nursing Students' Ecocentric, Anthropocentric and Anti- pathetic Attitudes towards the Environment
}

\author{
Media Subasi Baybuga, RN, PhD ${ }^{1^{*}}$ and Serap Gökbel Sönmez, RN, MSN ${ }^{2}$ \\ ${ }^{1}$ Professor, Nursing Department, Faculty of Health Sciences, Mugla Sitki Kocman University, Mugla, Turkey \\ ${ }^{2}$ Nurse, Ege University Medical Faculty Hospital, Izmir, Turkey
}

*Corresponding author: Media Subasi Baybuga, RN, PhD, Professor, Nursing Department, Faculty of Health Sciences, Mugla Sitki Kocman University, Mugla, Turkey, Tel: +90-252-211-1727, Fax: +90-252-211-18-80

\begin{abstract}
Aim: The study was conducted to determine the ecocentric, anthropocentric and antipathetic attitudes of nursing students towards the environment.

Material and methods: This is a descriptive and the sample of the study was 244 nursing students. Ecocentric, Anthropocentric and Antipathetic Attitudes Towards The Environment Scale was used for data collection.

Results: The average scores obtained by the students in the Ecocentric Attitude and Anthropocentric Attitude were found to be $62.56 \pm 7.89$ and $42.18 \pm 7.98$. It was seen that female students had an average Ecocentric Attitude score of $63.28 \pm 7.04$, whereas male students had an average Ecocentric Attitude score of $60.75 \pm 9.52$ ( $p<0.05$ ). Female students had an average Antipathetic Attitude score of $15.18 \pm 7.36$, whereas male students had an average Antipathetic Attitude score of $18.24 \pm 6.68$ ( $p<0.05$ ). A statistically significant difference was found between the students who stated that they participated in environmental activities and those who stated they did not in the Anthropocentric Attitude sub-dimension. In the Ecocentric Attitude and Antipathetic Attitude sub-dimensions of the scale, the participants who stated that they followed news related to the environment scored $63.57 \pm 6.89$ and $15.74 \pm 7.36$ respectively, whereas those who stated they did not follow news related to the environment scored $52.86 \pm 10.17$ and $19.04 \pm 5.93$ respectively, $(p<0.05)$.
\end{abstract}

Conclusion: The nursing students have a high average Ecocentric Attitude score, an average Anthropocentric Attitude score and a low average Antipathetic Attitude score.

\section{Keywords}

Nursing, Students, Ecocentric, Anthropocentric, Antipathetic attitudes, Environment

\section{Introduction}

Environmental problems have become global and begun to threaten life on the planet, which has led humans to reconsider their relationship with the environment, and their attitudes, behaviors, duties and responsibilities towards it, and to redefine the importance of ecological culture and environmental awareness $[1,2]$. Using the environment in which we live in a more effective, sustainable and efficient manner is only possible by creating a society with environmental awareness [3]. Raising environmentally-conscious and sensitive individuals is the most effective way to solve environmental problems. This requires a change in attitudes, knowledge and value judgments related to the environment, leading to a change individual behaviors. Forming positive attitudes towards and positive value judgments about the environment is possible through environmental education. The ultimate goal of environmental education is achieve behavioral changes although there will certainly be environmentally insensitive individuals and some individuals will continue to damage the environment $[4,5]$.

It is obvious that the knowledge, behaviors and attitudes of adolescents related to the environment will directly or indirectly affect their future decisions about natural resources, how to use them and how to sustain them [6]. The attitudes of young people towards the environment are important particularly because they are affected by today's activities and will need to find solutions. In this sense, an effective environmental ed-

Citation: Baybuga MS, Sönmez SG (2019) Turkish Nursing Students' Ecocentric, Anthropocentric and Antipathetic Attitudes towards the Environment. Int Arch Nurs Health Care 5:138. doi. org/10.23937/2469-5823/1510138

Accepted: December 21, 2019: Published: December 23, 2019

Copyright: (C) 2019 Baybuga MS, et al. This is an open-access article distributed under the terms of the Creative Commons Attribution License, which permits unrestricted use, distribution, and reproduction in any medium, provided the original author and source are credited. 
ucation is of great importance for school-aged children. Students always play an active role in activities aimed at raising environmental awareness [7]. If young people have a strong knowledge of and positive attitudes towards the environment, this facilitates the solving of environmental problems; in addition, environmental education programs are effective in improving the knowledge, attitudes and behaviors of students through intergenerational interaction [8]. Changes in behaviors and attitudes occur as a result of a change in the level of knowledge and values are instilled through new information. In this sense, an environmental education shapes positive environmental attitudes and values in young people $[9,10]$ and the education of individuals and improvement of their environmental attitudes play important roles in the prevention and solution of environmental problems [11].

Ecocentric and Anthropocentric approaches reflect the ethical approaches of humans towards the nature. Ecocentric thinking indicates that the individual sees the world as having its own intrinsic value, believes that nature must be protected without putting one's self interest first and acts accordingly. Such individuals value plants, animals and humans the same, believe in the recovery and recycling of wastes, use water and energy efficiently and place particular importance on the protection of the environment. Anthropocentric individuals support the protection of the environment because it is indispensable to improving the quality of life and the continued existence of humans. According to such individuals, the environment must be protected for interests of humanity and protecting the environment means protecting humanity. Environmental pollution (air, soil and water pollution, etc.) must be prevented because it threatens our health. Anthropocentric attitudes are based on the utilitarian philosophy. The efforts in this field are particularly focused on investigating motives behind the protection of environment and the value judgments of individuals related to the disruption of environment [12].

The fact that environmental problems have reached a serious point in today's world and become a globally significant threat against the health of communities requires that all sections of society, but in particular health professionals, be more sensitive towards the environment and take the necessary measures related to this subject. On this point, nurses, who have the prime importance in the care and education of healthy/unhealthy individuals, have significant responsibilities [13]. Nursing is a concept that can be defined based on ecology and greatly contributes to the global and holistic improvement of sustainability [14]. As members of the health care team, nurses spend more time within the community while performing their roles, and providing care and consultancy in matters related to environmental health are included in protective health services. This indicates that nurses play an important role in terms of creating environmental awareness within society. In this sense, nurses must be aware of the environmental problems which threaten human health, analyze these problems, demonstrate comprehensive knowledge about environmental health problems in order to fulfill their individual and professional responsibilities and know what their roles are with regard to environmental health [15]. Moreover, nurses must increase their awareness about both the effects of the environment on human health and the effects of health care services on the environment, adopt sustainable health care principles, develop an environmental way of thinking and gain an environment-centered ethical approach [13]. For this reason, it should be remembered that creating environmental awareness and developing positive environmental attitudes in nursing students, who will work as nurses in the future, is an important step towards improving environmental health, creating a sustainable environment and solving environmental problems.

\section{Material and Methods}

\section{Type of study}

This is descriptive study.

\section{Sample of the research}

This is a descriptive study conducted in order to reveal the ecocentric (environment-centered), anthropocentric (human-centered) and antipathetic attitudes of nursing students towards environment. The population of the study was made up of $1^{\text {st }}, 2^{\text {nd }}, 3^{\text {rd }}$ and $4^{\text {th }}$ year students attending the Nursing Department, Faculty of Health Sciences, Muğla Sitki Koçman University during the Spring semester of the 2014-2015 academic year.

\section{Data collection instruments}

A survey form containing questions related to the sociodemographic characteristics of the participants and the Ecocentric, Anthropocentric and Antipathetic Attitudes Towards The Environment Scale developed by Erten [12] were used for data collection. The scale consists of three sub-dimensions and is a 7-point Likert scale ranging from 'strongly disagree' to 'strongly agree'. The scale contains 26 items. The first 11 items measure Ecocentric Attitude, the next 8 items measure Anthropocentric Attitude and the last 7 items measure Antipathetic Attitude towards environment. There are no reverse items in the scale. The minimum and maximum scores obtainable are 11-77 for the Ecocentric dimension, 8-56 for the Anthropocentric dimension and 7-49 for the Antipathetic dimension. Cronbach's Alpha value is 0.77 for the Ecocentric dimension, 0.78 for the Anthropocentric dimension and 0.92 for the Antipathetic dimension. In this study, Cronbach's Alpha value was found to be 
0.77 for the Ecocentric dimension, 0.80 for the Anthropocentric dimension and 0.83 for the Antipathetic dimension.

\section{Data collection}

The study data were collected by the researchers during students' rest periods in March to April 2015. After distributing the data form, the participants were informed about the subject and purpose of the study and explained that participation was on voluntary basis and the data would be kept confidential. Each questionnaire took 15 minutes on average to complete.

\section{Data analysis}

The sociodemographic characteristics of the students were considered as independent variables and the scale sub-dimension scores were considered as dependent variables. Statistical analysis of the data obtained in the study was performed using descriptive statistics, Student $t$ test, Analysis of Variance, Kruskal-Wallis and Mann-Whitney $U$ tests on the SPSS 20.0 program.

\section{Ethical approval}

Necessary permits were obtained from the Scientific Research Ethics Board (Number: 07/01/2015-9) and the Rectorate of Muğla Sitki Koçman University. The participants were informed about the subject and purpose of the study and explained that participation was on voluntary basis. The confidentiality of data was maintained throughout the study.

\section{Results}

The results of this study provide knowledge related to the attitudes of nursing students towards the envi-

Table 1: The distribution of average scores obtained by the nursing students from the ecocentric, anthropocentric and antipathetic attitudes towards environment scale ( $n: 244)$.

\begin{tabular}{|l|l|l|}
\hline Sub-Dimentions of the Scale & Ort \pm SD & Min-Max \\
\hline Ecocentric centered attitude & $62.56 \pm 7.89$ & $32-77$ \\
\hline Anthropocentric centered attitude & $42.18 \pm 7.98$ & $14-56$ \\
\hline $\begin{array}{l}\text { Antipathetic attitudes towards } \\
\text { environment }\end{array}$ & $16.05 \pm 7.29$ & $7-45$ \\
\hline
\end{tabular}

Table 2: Nursing students demographics (n: 244).

\begin{tabular}{|l|l|l|}
\hline Characteristics & $\mathbf{n}$ & $\%$ \\
\hline Grade & & \\
Freshman & 26 & 10.7 \\
Second & 51 & 20.9 \\
Third & 99 & 40.6 \\
\hline Fourth & 68 & 27.9 \\
\hline Gender & & \\
Female & 175 & 71.7 \\
Male & 69 & 28.3 \\
\hline
\end{tabular}

\begin{tabular}{|c|c|c|}
\hline $\begin{array}{l}\text { Age } \\
18-21 \\
22 \text { and upper }\end{array}$ & $\begin{array}{l}138 \\
106\end{array}$ & $\begin{array}{l}56.6 \\
43.4\end{array}$ \\
\hline $\begin{array}{l}\text { Marital status } \\
\text { Married } \\
\text { Unmarried }\end{array}$ & $\begin{array}{l}3 \\
241\end{array}$ & $\begin{array}{l}1.2 \\
98.8\end{array}$ \\
\hline $\begin{array}{l}\text { Region of come from (n: 207) } \\
\text { Aegean Region } \\
\text { Mediterranean Region } \\
\text { Marmara Region } \\
\text { Central Anatolian Region } \\
\text { Southeastern Anatolian Region } \\
\text { Eastern Anatolian Region } \\
\text { Black Sea Region } \\
\text { Abroad }\end{array}$ & $\begin{array}{l}74 \\
47 \\
23 \\
17 \\
19 \\
14 \\
11 \\
2\end{array}$ & $\begin{array}{l}35.7 \\
22.7 \\
11.1 \\
8.2 \\
9.2 \\
6.8 \\
5.3 \\
1.0\end{array}$ \\
\hline $\begin{array}{l}\text { Graduated school (n: 242) } \\
\text { High School } \\
\text { Anatolian and Science High School } \\
\text { Health Vocational High School } \\
\text { Others* }\end{array}$ & $\begin{array}{l}100 \\
103 \\
26 \\
13\end{array}$ & $\begin{array}{l}41.4 \\
42.3 \\
10.8 \\
5.5\end{array}$ \\
\hline $\begin{array}{l}\text { Stracture of family }(\mathbf{n}: \mathbf{2 4 0}) \\
\text { Nuclear } \\
\text { Wide } \\
\text { Fragmented family }\end{array}$ & $\begin{array}{l}189 \\
39 \\
12\end{array}$ & $\begin{array}{l}78.8 \\
16.3 \\
5.3\end{array}$ \\
\hline $\begin{array}{l}\text { The status of income and expenditure } \\
\text { (n: 243) } \\
\text { Expenditure lower than their income } \\
\text { Equal to their expenditure } \\
\text { Expenditure higher than their income }\end{array}$ & $\begin{array}{l}77 \\
142 \\
24\end{array}$ & $\begin{array}{l}31.7 \\
58.4 \\
9.9\end{array}$ \\
\hline $\begin{array}{l}\text { Having a pet } \\
\text { Yes } \\
\text { No }\end{array}$ & $\begin{array}{l}46 \\
198\end{array}$ & $\begin{array}{l}18.9 \\
81.1\end{array}$ \\
\hline $\begin{array}{l}\text { Growing plants } \\
\text { Yes } \\
\text { No }\end{array}$ & $\begin{array}{l}93 \\
151\end{array}$ & $\begin{array}{l}38.1 \\
61.9\end{array}$ \\
\hline $\begin{array}{l}\text { Talking about environment with social or } \\
\text { family member } \\
\text { Yes } \\
\text { No }\end{array}$ & $\begin{array}{l}190 \\
54\end{array}$ & $\begin{array}{l}77.9 \\
22.1\end{array}$ \\
\hline $\begin{array}{l}\text { Following news related to environment } \\
\text { Yes } \\
\text { No }\end{array}$ & $\begin{array}{l}186 \\
58\end{array}$ & $\begin{array}{l}76.2 \\
23.8\end{array}$ \\
\hline $\begin{array}{l}\text { Listening news related to Environment } \\
\text { Yes } \\
\text { No }\end{array}$ & $\begin{array}{l}221 \\
23\end{array}$ & $\begin{array}{l}90.6 \\
9.4\end{array}$ \\
\hline $\begin{array}{l}\text { Participanding activities related to } \\
\text { Environment } \\
\text { Yes } \\
\text { No }\end{array}$ & $\begin{array}{l}76 \\
168\end{array}$ & $\begin{array}{l}31.1 \\
68.9\end{array}$ \\
\hline $\begin{array}{l}\text { Volunteered environmental organization } \\
\text { or community } \\
\text { Yes } \\
\text { No }\end{array}$ & $\begin{array}{l}35 \\
209\end{array}$ & $\begin{array}{l}14.3 \\
85.7\end{array}$ \\
\hline
\end{tabular}

"Industrial Vocational High School, Religious Vocational High School, etc. 
ronment. In this study, the average scores obtained by the students in Ecocentric Attitude, Anthropocentric Attitude and Antipathetic Attitude sub-dimensions of the scale were found to be $62.56 \pm 7.89,42.18 \pm 7.98$ and $16.05 \pm 7.29$ respectively (Table 1 ). In the study, $56.6 \%$ of the nursing students were in the 18-21 age group and $43.4 \%$ were in the 22 and above age group (Table 2). Average scores of the 18-21 age group and the 22 and above age group were $62.18 \pm 7.91$ and $63.06 \pm 7.86$ in the Ecocentric Attitude sub-dimension, $42.05 \pm 7.79$

Table 3: Average scores obtained by the nursing students from the ecocentric, anthropocentric and antipathetic attitudes towards environment scale depending on certain demographic characteristics ( $n: 244)$.

\begin{tabular}{|c|c|c|c|c|c|}
\hline $\begin{array}{l}\text { Sub-Dimentions of the } \\
\text { Scale }\end{array}$ & Variables & $\mathbf{n}$ & Ort \pm SD & $\begin{array}{l}\text { Statistical } \\
\text { Evaluation }\end{array}$ & $\mathbf{P}^{*}$ \\
\hline & Gender & & & & \\
\hline Ecocentric centered attitude & $\begin{array}{l}\text { Female } \\
\text { Male }\end{array}$ & $\begin{array}{l}175 \\
69\end{array}$ & $\begin{array}{l}63.28 \pm 7.04 \\
60.75 \pm 9.52\end{array}$ & $\mathrm{t}: 2.27$ & 0.024 \\
\hline $\begin{array}{l}\text { Anthropocentric centered } \\
\text { attitude }\end{array}$ & $\begin{array}{l}\text { Female } \\
\text { Male }\end{array}$ & $\begin{array}{l}175 \\
69\end{array}$ & $\begin{array}{l}42.32 \pm 7.92 \\
41.82 \pm 8.17\end{array}$ & t: 0.440 & 0.661 \\
\hline $\begin{array}{l}\text { Antipathetic attitudes towards } \\
\text { environment }\end{array}$ & $\begin{array}{l}\text { Female } \\
\text { Male }\end{array}$ & $\begin{array}{l}175 \\
69\end{array}$ & $\begin{array}{l}15.18 \pm 7.36 \\
18.24 \pm 6.68\end{array}$ & $\mathrm{t}:-2.996$ & 0.003 \\
\hline & Age & & & & \\
\hline Ecocentric centered attitude & $\begin{array}{l}18-21 \\
22 \text { and upper }\end{array}$ & $\begin{array}{l}138 \\
106\end{array}$ & $\begin{array}{l}62.18 \pm 7.91 \\
63.06 \pm 7.86\end{array}$ & $\mathrm{t}:-0.868$ & 0.386 \\
\hline $\begin{array}{l}\text { Anthropocentric centered } \\
\text { attitude }\end{array}$ & $\begin{array}{l}18-21 \\
22 \text { and upper }\end{array}$ & $\begin{array}{l}138 \\
106\end{array}$ & $\begin{array}{l}42.05 \pm 7.79 \\
42.34 \pm 8.25\end{array}$ & $\mathrm{t}:-0.282$ & 0.778 \\
\hline $\begin{array}{l}\text { Antipathetic attitudes towards } \\
\text { environment }\end{array}$ & $\begin{array}{l}18-21 \\
22 \text { and upper }\end{array}$ & $\begin{array}{l}138 \\
106\end{array}$ & $\begin{array}{l}15.32 \pm 6.35 \\
17.00 \pm 8.30\end{array}$ & $\mathrm{t}:-1.784$ & 0.76 \\
\hline & Grade & & & & \\
\hline Ecocentric centered attitude & $\begin{array}{l}\text { Freshmen } \\
\text { Second } \\
\text { Third } \\
\text { Fourth }\end{array}$ & $\begin{array}{l}26 \\
51 \\
99 \\
68\end{array}$ & $\begin{array}{l}61.19 \pm 9.56 \\
61.60 \pm 8.46 \\
63.01 \pm 7.84 \\
63.16 \pm 6.79\end{array}$ & KW: 1.716 & 0.633 \\
\hline $\begin{array}{l}\text { Anthropocentric centered } \\
\text { attitude }\end{array}$ & $\begin{array}{l}\text { Freshmen } \\
\text { Second } \\
\text { Third } \\
\text { Fourth }\end{array}$ & $\begin{array}{l}26 \\
51 \\
99 \\
68\end{array}$ & $\begin{array}{l}41.88 \pm 7.32 \\
42.98 \pm 8.03 \\
42.75 \pm 7.56 \\
40.86 \pm 8.74\end{array}$ & KW: 1.686 & 0.640 \\
\hline $\begin{array}{l}\text { Antipathetic attitudes towards } \\
\text { environment }\end{array}$ & $\begin{array}{l}\text { Freshmen } \\
\text { Second } \\
\text { Third } \\
\text { Fourth }\end{array}$ & $\begin{array}{l}26 \\
51 \\
99 \\
68\end{array}$ & $\begin{array}{l}16.73 \pm 5.51 \\
14.66 \pm 6.28 \\
15.42 \pm 6.62 \\
17.75 \pm 9.10\end{array}$ & KW: 4.384 & 0.223 \\
\hline & Status of income and expenditure & & & & \\
\hline Ecocentric centered attitude & $\begin{array}{l}\text { Expenditure lower than their income } \\
\text { Equal to their expenditure } \\
\text { Expenditure higher than their income }\end{array}$ & $\begin{array}{l}77 \\
142 \\
24\end{array}$ & $\begin{array}{l}62.93 \pm 9.22 \\
62.59 \pm 7.10 \\
60.95 \pm 7.90\end{array}$ & KW: 1.555 & 0.460 \\
\hline $\begin{array}{l}\text { Anthropocentric centered } \\
\text { attitude }\end{array}$ & $\begin{array}{l}\text { Expenditure lower than their income } \\
\text { Equal to their expenditure } \\
\text { Expenditure higher than their income }\end{array}$ & $\begin{array}{l}77 \\
142 \\
24\end{array}$ & $\begin{array}{l}42.98 \pm 8.22 \\
41.85 \pm 8.07 \\
41.00 \pm 6.10\end{array}$ & KW: 2.815 & 0.245 \\
\hline $\begin{array}{l}\text { Antipathetic attitudes towards } \\
\text { environment }\end{array}$ & $\begin{array}{l}\text { Expenditure lower than their income } \\
\text { Equal to their expenditure } \\
\text { Expenditure higher than their income }\end{array}$ & $\begin{array}{l}77 \\
142 \\
24\end{array}$ & $\begin{array}{l}15.94 \pm 7.12 \\
16.04 \pm 7.59 \\
16.09 \pm 7.28\end{array}$ & KW: 0.934 & 0.624 \\
\hline & Having pet & & & & \\
\hline
\end{tabular}




\begin{tabular}{|c|c|c|c|c|c|}
\hline Ecocentric centered attitude & $\begin{array}{l}\text { Yes } \\
\text { No }\end{array}$ & $\begin{array}{l}46 \\
198\end{array}$ & $\begin{array}{l}64.86 \pm 6.20 \\
62.03 \pm 8.15\end{array}$ & t: 2.216 & 0.280 \\
\hline $\begin{array}{l}\text { Anthropocentric centered } \\
\text { attitude }\end{array}$ & $\begin{array}{l}\text { Yes } \\
\text { No }\end{array}$ & $\begin{array}{l}46 \\
198\end{array}$ & $\begin{array}{l}42.32 \pm 9.08 \\
41.91 \pm 7.70\end{array}$ & t: 1.077 & 0.283 \\
\hline \multirow[t]{2}{*}{$\begin{array}{l}\text { Antipathetic attitudes towards } \\
\text { environment }\end{array}$} & $\begin{array}{l}\text { Yes } \\
\text { No }\end{array}$ & $\begin{array}{l}46 \\
198\end{array}$ & $\begin{array}{l}14.69 \pm 6.56 \\
16.36 \pm 7.43\end{array}$ & $\mathrm{t}:-1.404$ & 0.162 \\
\hline & Growing plants & & & & \\
\hline Ecocentric centered attitude & $\begin{array}{l}\text { Yes } \\
\text { No }\end{array}$ & $\begin{array}{l}151 \\
93\end{array}$ & $\begin{array}{l}63.90 \pm 6.94 \\
60.39 \pm 8.84\end{array}$ & $\mathrm{t}: 3.442$ & 0.001 \\
\hline $\begin{array}{l}\text { Anthropocentric centered } \\
\text { attitude }\end{array}$ & $\begin{array}{l}\text { Yes } \\
\text { No }\end{array}$ & $\begin{array}{l}151 \\
93\end{array}$ & $\begin{array}{l}43.50 \pm 7.28 \\
40.04 \pm 8.61\end{array}$ & t: 3.357 & 0.001 \\
\hline \multirow[t]{2}{*}{$\begin{array}{l}\text { Antipathetic attitudes towards } \\
\text { environment }\end{array}$} & $\begin{array}{l}\text { Yes } \\
\text { No }\end{array}$ & $\begin{array}{l}151 \\
93\end{array}$ & $\begin{array}{l}15.29 \pm 7.07 \\
17.27 \pm 7.52\end{array}$ & t: -2.074 & 0.039 \\
\hline & Recidence area & & & & \\
\hline Ecocentric centered attitude & $\begin{array}{l}\text { Aegean Region } \\
\text { Mediterranean Region } \\
\text { Marmara Region } \\
\text { Central Anatolian Region } \\
\text { Southeastern Anatolian Region } \\
\text { Eastern Anatolian Region } \\
\text { Black Sea Region } \\
\text { Abroad }\end{array}$ & $\begin{array}{l}74 \\
47 \\
23 \\
17 \\
19 \\
14 \\
11 \\
2\end{array}$ & $\begin{array}{l}63.59 \pm 7.11 \\
63.80 \pm 7.96 \\
60.43 \pm 9.57 \\
62.58 \pm 6.27 \\
58.78 \pm 11.99 \\
62.92 \pm 7.04 \\
59.90 \pm 6.28 \\
62.53 \pm 8.09\end{array}$ & KW: 6.638 & 0.468 \\
\hline $\begin{array}{l}\text { Anthropocentric centered } \\
\text { attitude }\end{array}$ & $\begin{array}{l}\text { Aegean Region } \\
\text { Mediterranean Region } \\
\text { Marmara Region } \\
\text { Central Anatolian Region } \\
\text { Southeastern Anatolian Region } \\
\text { Eastern Anatolian Region } \\
\text { Black Sea Region } \\
\text { Abroad }\end{array}$ & $\begin{array}{l}74 \\
47 \\
23 \\
17 \\
19 \\
14 \\
11 \\
2\end{array}$ & $\begin{array}{l}41.56 \pm 9.31 \\
43.78 \pm 7.24 \\
40.82 \pm 5.21 \\
43.17 \pm 9.20 \\
40.73 \pm 10.85 \\
43.28 \pm 4.44 \\
44.18 \pm 8.08 \\
42.29 \pm 8.28\end{array}$ & KW: 6.593 & 0.472 \\
\hline \multirow[t]{2}{*}{$\begin{array}{l}\text { Antipathetic attitudes towards } \\
\text { environment }\end{array}$} & $\begin{array}{l}\text { Aegean Region } \\
\text { Mediterranean Region } \\
\text { Marmara Region } \\
\text { Central Anatolian Region } \\
\text { Southeastern Anatolian Region } \\
\text { Eastern Anatolian Region } \\
\text { Black Sea Region } \\
\text { Abroad }\end{array}$ & $\begin{array}{l}74 \\
47 \\
23 \\
17 \\
19 \\
14 \\
11 \\
2\end{array}$ & $\begin{array}{l}16.29 \pm 7.54 \\
14.12 \pm 5.66 \\
16.69 \pm 8.55 \\
17.88 \pm 7.46 \\
16.52 \pm 6.82 \\
15.21 \pm 7.22 \\
16.00 \pm 6.72 \\
25.00 \pm 4.24\end{array}$ & KW: 7.646 & 0.365 \\
\hline & $\begin{array}{l}\text { Participating in environmental } \\
\text { activities }\end{array}$ & & & & \\
\hline Ecocentric centered attitude & $\begin{array}{l}\text { Yes } \\
\text { No }\end{array}$ & $\begin{array}{l}76 \\
168\end{array}$ & $\begin{array}{l}63.98 \pm 7.61 \\
61.92 \pm 7.95\end{array}$ & t: 1.902 & 0.058 \\
\hline $\begin{array}{l}\text { Anthropocentric centered } \\
\text { attitude }\end{array}$ & $\begin{array}{l}\text { Yes } \\
\text { No }\end{array}$ & $\begin{array}{l}76 \\
168\end{array}$ & $\begin{array}{l}43.72 \pm 7.90 \\
41.48 \pm 7.94\end{array}$ & t: 2.039 & 0.043 \\
\hline \multirow[t]{2}{*}{$\begin{array}{l}\text { Antipathetic attitudes towards } \\
\text { environment }\end{array}$} & $\begin{array}{l}\text { Yes } \\
\text { No }\end{array}$ & $\begin{array}{l}76 \\
168 \\
\end{array}$ & $\begin{array}{l}15.72 \pm 8.45 \\
16.20 \pm 6.72\end{array}$ & $\mathrm{t}:-4.74$ & 0.636 \\
\hline & $\begin{array}{l}\text { Listening news related to } \\
\text { environment }\end{array}$ & & & & \\
\hline Ecocentric centered attitude & $\begin{array}{l}\text { Yes } \\
\text { No }\end{array}$ & $\begin{array}{l}221 \\
23\end{array}$ & $\begin{array}{l}63.57 \pm 6.89 \\
52.86 \pm 10.17\end{array}$ & U: 878.00 & 0.000 \\
\hline $\begin{array}{l}\text { Anthropocentric centered } \\
\text { attitude }\end{array}$ & $\begin{array}{l}\text { Yes } \\
\text { No }\end{array}$ & $\begin{array}{l}221 \\
23\end{array}$ & $\begin{array}{l}42.57 \pm 7.75 \\
38.47 \pm 9.30\end{array}$ & U: 1906.00 & 0.048 \\
\hline
\end{tabular}




\begin{tabular}{|l|l|l|l|l|l|}
\hline $\begin{array}{l}\text { Antipathetic attitudes towards } \\
\text { environment }\end{array}$ & $\begin{array}{l}\text { Yes } \\
\text { No }\end{array}$ & $\begin{array}{l}221 \\
23\end{array}$ & $\begin{array}{l}15.74 \pm 7.36 \\
19.04 \pm 5.93\end{array}$ & U: 1734.00 & $\mathbf{0 . 0 1 2}$ \\
\hline & $\begin{array}{l}\text { Talking about environment with social } \\
\text { or family member }\end{array}$ & & & \\
\hline Ecocentric centered attitude & Yes & No & 190 & $63.83 \pm 6.79$ & t: 4.920 \\
\hline $\begin{array}{l}\text { Anthropocentric centered } \\
\text { attitude }\end{array}$ & Yes & 54 & $58.11 \pm 9.72$ & $\mathbf{0 . 0 0 0}$ \\
\hline $\begin{array}{l}\text { Antipathetic attitudes towards } \\
\text { environment }\end{array}$ & Yes & 190 & $42.92 \pm 7.36$ & t: 2.740 & $\mathbf{0 . 0 0 7}$ \\
\hline
\end{tabular}

* $p<0.05$.

and $42.34 \pm 8.25$ in the Anthropocentric Attitude sub-dimension, and $15.32 \pm 6.35$ and $17.00 \pm 8.30$ in the Antipathetic Attitude sub-dimension. No statistically significant difference was found in any of the three sub-dimensions $(p>0.05)$ (Table 3$)$.

The present study, $31.7 \%$ of the students reported having a higher expenditure than their income and $58.4 \%$ stated that their income was equal to their expenditure (Table 2). The students who stated that their expenditure was higher than their income had an average Ecocentric Attitude score of $62.93 \pm 9.22$, an average Anthropocentric Attitude score of 42.98 \pm 8.22 and an average Antipathetic Attitude score of $15.94 \pm 7.12$, whereas the students who stated that their income was higher than their expenditure had an average Ecocentric Attitude score of $60.95 \pm 7.90$, an average Anthropocentric Attitude score of 41.00 \pm 6.10 and an average Antipathetic Attitude score of $16.09 \pm 7.28$ (Table 3 ).

In this study, $18.9 \%$ of the students had a pet and 38.1\% grew various plants (Table 2). In the Ecocentric Attitude, Anthropocentric Attitude and Antipathetic Attitude sub-dimensions of the scale, the students who had a pet scored $64.86 \pm 6.20,42.32 \pm 9.08$ and $14.69 \pm 6.56$ respectively (Table 3 ). Students who grew plants scored $63.90 \pm 6.94,43.50 \pm 7.28$ and $15.29 \pm$ 7.07 in the Ecocentric Attitude, Anthropocentric Attitude and Antipathetic Attitude sub-dimensions of the scale respectively (Table 3 ). Growing plants led to a significant difference in all three sub-dimensions of the scale $(p<0.05)$ (Table 3).

In the study, $71.7 \%$ of the students were female and $28.3 \%$ were male. It was seen that female students had an average Ecocentric Attitude score of $63.28 \pm 7.04$, whereas male students had an average Ecocentric Attitude score of $60.75 \pm 9.52(p<0.05)$. Female students had an average Antipathetic Attitude score of $15.18 \pm 7.36$, whereas male students had an average Antipathetic Attitude score of $18.24 \pm 6.68$ $(p<0.05)$ (Table 3). Also, one of results expected and found in this study was that students with high average Ecocentric and Anthropocentric Attitude scores would have low average Antipathetic Attitude scores.
In the present study, $31.1 \%$ of the participants stated that they participated in environmental activities and $14.3 \%$ stated that they volunteered at an environmental organization or community (Table 2). In this study, $77.9 \%$ of the students stated that they talked about the environment with their social circle or family members, $76 \%$ stated that they read news stories related to environmental problems and 90.6\% stated that they listened to news related to the environment (Table 2). In this study, $10.7 \%$ of the participants were first year students and $27.9 \%$ were fourth year students (Table 2). In the Ecocentric Attitude, Anthropocentric Attitude and Antipathetic Attitude sub-dimensions of the scale, the first year students scored $61.19 \pm 9.56,41.88 \pm 7.32$ and 16.73 \pm 5.51 respectively, whereas the fourth year students scored $63.16 \pm 6.79,40.86 \pm 8.74$ and $17.75 \pm 9.10$ respectively. No statistically significant difference was found in any of the three sub-dimensions $(p>0.05)$ (Table 3).

In the study, $35.7 \%$ of the students were from the Aegean Region and 9.2\% were from the Southeastern Anatolian Region (Table 2). In the Ecocentric Attitude, Anthropocentric Attitude and Antipathetic Attitude sub-dimensions of the scale, the students from the Aegean Region scored 63.59 $\pm 7.11,41.56 \pm 9.31$ and $16.29 \pm 7.54$ respectively, whereas the students from the Southeastern Anatolian Region scored 58.78 $\pm 11.99,40.73 \pm 10.85$ and $16.52 \pm 6.82$ respectively. No statistically significant difference was found in any of the three sub-dimensions $(p>0.05)$ (Table 3$)$.

\section{Discussion}

The results of this study provide knowledge related to the attitudes of nursing students towards the environment. In the study, $56.6 \%$ of the nursing students were in the $18-21$ age group and $43.4 \%$ were in the 22 and above age group (Table 2). Average scores of the 18-21 age group and the 22 and above age group were $62.18 \pm 7.91$ and $63.06 \pm 7.86$ in the Ecocentric Attitude sub-dimension, $42.05 \pm 7.79$ and $42.34 \pm 8.25$ in the Anthropocentric Attitude sub-dimension, and $15.32 \pm 6.35$ and $17.00 \pm 8.30$ in the Antipathetic Attitude sub-dimension. No statistically 
significant difference was found in any of the three sub-dimensions ( $p>0.05$ ) (Table 3). Similarly, Çelik, et al. [16] and Ulas and Uncu [17] found that there was no a significant different in terms of environmental awareness between students with different ages. Environmental attitudes of young people develop at an early age [18], and environmental attitudes improve with increasing age $[9,19,20]$.

In this study, $31.7 \%$ of the students reported having a higher expenditure than their income and $58.4 \%$ stated that their income was equal to their expenditure ( $\mathrm{Ta}$ ble 2). The students who stated that their expenditure was higher than their income had an average Ecocentric Attitude score of $62.93 \pm 9.22$, an average Anthropocentric Attitude score of $42.98 \pm 8.22$ and an average Antipathetic Attitude score of $15.94 \pm 7.12$, whereas the students who stated that their income was higher than their expenditure had an average Ecocentric Attitude score of $60.95 \pm 7.90$, an average Anthropocentric Attitude score of $41.00 \pm 6.10$ and an average Antipathetic Attitude score of $16.09 \pm 7.28$ (Table 3 ). The attitudes of students towards the environment are affected by their economic status [7]. It was found in a study that income level of the family had an effect on the attitudes of students towards the environment and students from middle-income families were found to have a significantly higher score on the scale [16]. It was found a significant different in terms of environmental awareness between students with different income levels [11], and also Çelik, et al. [16], Karakuş, et al. [20], noted that students had an increased awareness related to the protection of nature and the environment with increasing income level. However, in other studies, Ulas and Uncu [17] and Çinar, et al. [21] and found that there was no significant difference between environmental attidude and economic status.

In this study, $18.9 \%$ of the students had a pet and $38.1 \%$ grew various plants (Table 2). In the Ecocentric Attitude, Anthropocentric Attitude and Antipathetic Attitude sub-dimensions of the scale, the students who had a pet scored $64.86 \pm 6.20,42.32 \pm 9.08$ and 14.69 \pm 6.56 respectively (Table 3 ). Students who grew plants scored $63.90 \pm 6.94,43.50 \pm 7.28$ and $15.29 \pm 7.07$ in the Ecocentric Attitude, Anthropocentric Attitude and Antipathetic Attitude sub-dimensions of the scale respectively (Table 3 ). Growing plants led to a significant difference in all three sub-dimensions of the scale ( $p$ $<0.05$ ) (Table 3). It is noted in the literature that individuals who care for plants and animals have a greater awareness of the need to protect the environment and take part in non-governmental organizations related to the protection of the environment more frequently than those who do not [22]. Önder [23] found that having a pet did not lead to a significant difference in terms of environmental attitude scores, which indicates that this variable does not have any effect on environmental attitude.
In the study, the average scores obtained by the students in Ecocentric Attitude, Anthropocentric Attitude and Antipathetic Attitude sub-dimensions of the scale were found to be $62.56 \pm 7.89,42.18 \pm 7.98$ and $16.05 \pm$ 7.29 respectively (Table 1 ). Karahan Okuroğlu [13] nursing students were found to have a high Anthropocentric Attitude score $(62 \pm 8.82)$ and the average scores obtained by nursing students in Ecocentric Attitude and Antipathetic Attitude sub-dimensions were found to be $43.44 \pm 7.80$ and $18.10 \pm 8.66$ respectively. The students were found to have high Ecocentric Attitudeand Anthropocentric Attitude scores and a low Antipathetic Attitude score. A high average score in the Anthropocentric Attitude sub-dimension was not an expected result, because the Anthropocentric Attitude involves ideas based on humans' self-interest. According to the Anthropocentric Attitude, humans protect the nature and the environment for their own interests. A high level of Anthropocentric Attitude may not be beneficial for the protection of the environment in the long run [22]. Nursing, midwifery and medical students were found to have quite high environmental attitude scores in studies using different environmental attitude scales $[9,19]$. This finding indicates that nursing education positively affects the development of an environmental attitude. High Ecocentric Attitude and Anthropocentric Attitude scores obtained by nursing students may be associated with the inclusion of the concept of the environment and holistic and humanistic values in nursing education. The fact that the concept of the environment is emphasized in all aspects of nursing education supports the adoption of the ecocentric approach, and the humanistic foundation of the nursing profession supports the development of anthropocentric attitudes in nursing students [13]. In this sense, planned efforts are required to diminish antipathetic attitudes regarding the protection of the environment. It is necessary to organize environmental education studies and educate individuals who have an awareness of environmental issues.

In the present study, $71.7 \%$ of the students were female and $28.3 \%$ were male. It was seen that female students had an average Ecocentric Attitude score of $63.28 \pm 7.04$, whereas male students had an average Ecocentric Attitude score of $60.75 \pm 9.52(p<0.05)$. Female students had an average Antipathetic Attitude score of $15.18 \pm 7.36$, whereas male students had an average Antipathetic Attitude score of $18.24 \pm$ $6.68(p<0.05)$ (Table 3). Also, one of results expected and found in this study was that students with high average Ecocentric and Anthropocentric Attitude scores would have low average Antipathetic Attitude scores. This can be explained as related to women's traditionally being responsible for taking care of the home and children, and their concerns regarding nature and the environment and the need for a clean and safe environment for childcare, well-being and survival. 
In the studies conducted by Şenyurt, et al. [11], Çelik, et al. [16] Çinar, et al. [21], Demirel, et al. [24] Levine and Strube [25], Lieflander and Bogner [26] found that environmental attitudes did not differ by gender. Ek, et al. [9], Ulas and Uncu [17], Özmen, et al. [19], Sam, et al. [27], Bodur and Taşocak [28] found a statistically significant difference between genders in terms of scores obtained from the Environmental Attitude Scale and determined that female students had higher Environmental Attitude scores than male students. Also, it was seen in the studies conducted by Karahan Okuroğlu [13] and Duman-Yüksel and Özkazanç [29] revealed that female nursing students had significantly higher Ecocentric Attitude scores than male students. Tikka, et al. [30] found that female students tended to assume more environmental responsibility than male students and the difference was statistically significant. In contrast to these studies, Tindall, et al. [31] stated that although females were more likely to engage in environmental behaviors and demonstrated a high level of concern, they did not demonstrate high level of activism compared to males. Similarly, Ünver, et al. [32] found in their study performed with nurses that female nurses had higher average Environmental Attitude and Awareness scores than male nurses. The fact that female students are usually found to have a higher degree of environmental awareness than male students might be associated with gender roles. The ideal image associated with women in society and culture expects women to be more concerned about the environment and act more confidently and sensitively to solve specific problems. Considering that children spend more time with their mothers than other family members, this is believed to contribute greatly to developing positive environmental attitudes and awareness in children, who will shape the society of the future [16].

In this study, $31.1 \%$ of the participants stated that they participated in environmental activities and $14.3 \%$ stated that they volunteered at an environmental organization or community (Table 2). This result indicated that the environmental non-governmental organizations did not have sufficient outreach to and were not sufficiently supported by students. In other studies, $10.0 \%$ in Şenyurt, et al.'s [11], $7.0 \%$ in Sayan and Kaya's [15] 2.9\% in Özmen, et al.'s [19] and 20.0\% in Ozturk and Enez's [33] of participants were determined to be members of an environmental organization. Özmen, et al. [19], Ek, et al. [9], Çelik, et al. [16], Kandak [34], Sayan and Kaya [15] and Ünver, et al. [32] found that $14.1 \%, 22.7 \%, 20.5 \%, 37.4 \%$, $12.6 \%$ and $74.7 \%$ respectively of the students participated in environmental activities. A statistically significant difference was found between students who stated that they participated in environmental activities and those who stated they did not in the Anthropocentric Attitude sub-dimension $(p<0.05)$, whereas no statistically significant difference was found in the other sub-dimensions ( $p>0.05$ ) (Table 3). Sayan and Kaya [15], Ünver, et al. [32], Beser, et al. [35], found that those who participated in environmental activities had higher Environmental Attitude scores than those who did not. Ek, et al. [9] found a statistically significant difference between students who participated in environmental activities and students who did not in terms of average scores obtained from the Environmental Attitude Scale and in support of the aforementioned studies; students who participated in environmental activities were found to have higher Environmental Attitude scores compared than those who did not. Considering that this rate is also an indication of students' interest in general environmental problems, we believe that the reason behind the lack of awareness about and participation in environmental activities should be investigated. Also, Sayan and Kaya [15] emphasize that non-governmental organizations should develop environment-related activities in educational institutions, in particular in universities, and inform students about them. It is known that non-governmental organizations play an important role in educating students to be individuals with a high degree of environmental awareness. In this sense, nursing students should be encouraged to be members of non-governmental organizations and participate in environmental activities.

In this study, $77.9 \%$ of the students stated that they talked about the environment with their social circle or family members, $76 \%$ stated that they read news stories related to environmental problems and $90.6 \%$ stated that they listened to news related to the environment (Table 2). In the Ecocentric Attitude and Antipathetic Attitude sub-dimensions of the scale, the participants who stated that they followed news related tothe environment scored $63.57 \pm 6.89$ and $15.74 \pm 7.36$ respectively, whereas those who stated they did not follow news related to the environment scored $52.86 \pm 10.17$ and $19.04 \pm 5.93$ respectively, and a statistically significant difference was found in both sub-dimensions $(p<0.05)$. Also, in the Anthropocentric Attitude and Antipathetic Attitude sub-dimensions of the scale, the participants who stated that they talked about the environment with their social circle or family members scored $63.83 \pm 6.79$ and $42.92 \pm 7.36$ respectively, whereas those who stated they did not scored $58.11 \pm 9.72$ and 39.59 \pm 9.47 respectively and a statistically significant difference was found in both sub-dimensions $(p<0.05)$ (Table 3). $66.3 \%$ of the participants stated that they talked with their family members about environmental issues in Kandak's [34] study, while this was 9.6\% for Şenyurt, et al. [11] and $48.3 \%$ for Sayan and Kaya [15] and 38.8\% for Özmen, et al. [19]. Çelik, et al. [16] found that the average score from the scale of participants who talked with their family members about 
environmental issues was significantly higher than for those who did not and noted that talking about environmental issues was effective in creating environmental awareness and positive attitudes in individuals. Ensuring individuals adopt positive environmental attitudes is important for creating sufficient environmental awareness and a lack of education regarding the environment makes it more difficult to take the necessary steps to protect it and to solve environmental problems.

In this study, $10.7 \%$ of the participants were first year students and $27.9 \%$ were fourth year students (Table 2). In the Ecocentric Attitude, Anthropocentric Attitude and Antipathetic Attitude sub-dimensions of the scale, the first year students scored $61.19 \pm 9.56$, $41.88 \pm 7.32$ and $16.73 \pm 5.51$ respectively, whereas the fourth year students scored $63.16 \pm 6.79,40.86$ \pm 8.74 and $17.75 \pm 9.10$ respectively. No statistically significant difference was found in any of the three sub-dimensions ( $p>0.05$ ) (Table 3). Ek, et al. [9], Şenyurt, et al. [11] and Çelik, et al. [16] found a significant difference between the years of study in terms of Environmental Attitude scores. In another study, an increase was found in average Environmental Attitude scores from the first year to the fourth year of university $[17,27,35]$. In support of this finding, Bodur and Taşocak [29] found a statistically significant difference between years of study in terms of Environmental Awareness scores. It is possible to say that students who have just started university are not very conscious about the environment and do not know about environmental organizations and that they become informed through courses related to environmental issues and introduced to environmental organizations, which raise their level of awareness.

In the study $35.7 \%$ of the students were from the Aegean Region and 9.2\% were from the Southeastern Anatolian Region (Table 2). In the Ecocentric Attitude, Anthropocentric Attitude and Antipathetic Attitude sub-dimensions of the scale, the students from the Aegean Region scored $63.59 \pm 7.11,41.56 \pm 9.31$ and $16.29 \pm 7.54$ respectively, whereas the students from the Southeastern Anatolian Region scored 58.78 $\pm 11.99,40.73 \pm 10.85$ and $16.52 \pm 6.82$ respectively. No statistically significant difference was found in any of the three sub-dimensions ( $p>0.05$ ) (Table 3 ). Where their families live or the place where they grew up are believed have an influence on the environmental attitudes of students. Considering the relationship between the place where students lived for the longest amount of time and their average "Environmental Attitude Scale" scores, it was found that students who had mostly lived in urban areas had a higher average score than others [19]. Similarly, Ek, et al. [9] found a statistically significant difference between students who had mostly lived in urban areas and students who had mostly lived in villages in terms of average Environmental Attitude scores. And also Ulas and Uncu [17] found a statistically significant difference between the place where students lived. It was expected that students who had lived mostly in urban areas, where environmental problems are more prominent, would have a higher degree of environmental awareness [19]. Çinar, et al. [20] and Kandak [34] found no significant difference between students in terms of Environmental Attitude scores depending on where their families lived. Demirel, et al. [24] found no significant relationship between the place where students had lived for the longest period of time and their environmental awareness. This result shows that the size and location of the place of residence may shape environmental attitudes. In support of this idea, Tikka, et al. [30] found that students from southern Finland, where the population density is the highest, had the most positive attitudes toward environment. In this sense, we can say that individuals who live in crowded urban areas are more likely to become aware of existing problems and adopt a sympathetic attitude towards nature and the environment. In densely populated areas, where active environmental movements and activities are available, environmental issues attract the attention of students and we can suggest that the considerably more intense environmental problems found in the centers of large cities have the effect of raising the awareness of students regarding environmental issues.

\section{Conclusions}

The students were found to have a high Ecocentric Attitude score (62.56 \pm 7.89$)$ and Anthropocentric Attitude score (42.18 \pm 7.98$)$ and a low Antipathetic Attitude score $(16.05 \pm 7.29)$. In this study conducted in order to determine the environmental attitudes of university students, it was seen that the students had a positive attitude towards the environment.

Based on the results of the study, it is suggested environmental topics and courses be included more widely in the nursing curricula, and also Syllabi should be designed to include environmental problems to increase knowledge and awareness of students and to acquire a positive attitude, that students should have the opportunity to participate more in scientific activities such as panels, seminars, and conferences, and there should be more cooperation with other organizations and the media to promote and provide environmental awareness. In addition, it is suggested that future research should focus on the environmental attitudes of nursing and other health care students, in different regions using larger sample groups, as well as on students in other disciplines.

\section{Author Contribution}


MSB and SGS were responsible for the study concep on and design. MSB and SGS performed the data analysis and responsible for the drawing of the manuscript.

\section{Authorship Statement}

MSB and SGS design of the study, data collection, analysis, interpretation of data, manuscript drafting and revising. All authors read and approved the final manuscript to be published.

\section{Conflicts of Interest and Source of Funding}

There is no conflict of interest and financial interest in this study. The authors received no financial support for the research, authorship, and/or publication of this article.

\section{Acknowledgements}

We would like to thank the nursing students who participated in the study.

\section{References}

1. Atli $\mathrm{K}$, Uzun N (2009) Öğrencilerin çevreye yönelik ilgi, düşünce ve davranişlari arasindaki korelasyonun incelenmesi. Erzincan University Journal of the Institute of Science and Technology 2: 197-215.

2. Hoşgör H, Hoşgör DG, Tosun NK (2015) Sağlik bilimleri fakültesi öğrencilerinin çevreye yönelik tutumlarinin belirlenmesi: Kiyaslamali Bir Analiz. Sağlik Bilimleri ve Meslekleri Dergisi 2: 198-208.

3. Aydin F, Çepni O (2012) Illköğretim ikinci kademe öğrencilerinin çevreye yönelik tutumlarinin bazi değişkenler açisindan incelenmesi (Karabük İli Örneği). Dicle Üniversitesi Ziya Gökalp Eğitim Fakültesi Dergisi 18: 189-207.

4. Aslan O, Sağir ŞU, Cansaran A (2008) Çevre tutum ölçeği uyarlanmasi ve ilköğretim öğrencilerinin çevre tutumlarinin belirlenmesi. Ahmet Keleşoğlu Eğitim Fakültesi Dergisi 25 283-295.

5. Rahman NA (2016) Knowledge, internal, and environmental factors on environmental care behaviour among aboriginal students in Malaysia. International Journal of Environmental \& Science Education 11: 5349-5366.

6. Meinhold JL, Malkus AJ (2005) Adolescent environmental behaviors: Can knowledge, attitudes, and self-efficacy make a difference? Environment and Behavior 37: 511-532.

7. Müderrisoğlu H, Altanlar A (2011) Attitudes and behaviors of undergraduate students toward environmental issues. Int J Environ Sci Tech 8: 159-168.

8. Ehrampoush MH, Moghadam MHB (2005) Survey of knowledge, attitude and practice of Yazd University of medical sciences students about solid wastes disposal and recycling. Iranian J Env Health Sci Eng 2: 26-30.

9. Ek Nurcan H, Kiliç N, Öğdüm P, Düzgün G (2009) Adnan menderes üniversitesinin farkli akademik alanlarinda öğrenim gören ilk ve son sinif öğrencilerinin çevre sorunlarina yönelik tutumlari ve duyarliliklari. Kastamonu Eğitim Dergisi 17: 125-136.

10. Erten S (2005) Okul öncesi öğretmen adaylarinda çevre dostu davranişlarin araştirilmasi. Hacettepe Üniversitesi Eğitim Fakültesi Dergisi 28: 91-100.

11. Şenyurt A, Temel AB, Ş Özkahraman (2011) Üniversite öğrencilerinin çevresel konulara duyarliliklarinin incelenmesi. SDÜ Sağlik Bilimleri Enstitüsü Dergisi 2: 8-14.
12. Erten S, Çevre Merkezli, İnsan Merkezli ve Çevreye Yönelik Antipatik Tutum Ölçeğinin Türkçeye Uyarlama Çalişmasi. EJER 28: 67-74.

13. Karahan Okuroğlu G (2012) Hemşirelik eğitiminin öğrencilerin çevreye yönelik tutumlarina etkisi. Hemşirelikte Araştirma Geliştirme Dergisi 3: 27-38.

14. Anaker A, Nilson M, Holmer A, Elf M (2015) Nurses' perceptions of climate and environmental issues: A qualitative study. J Adv Nurs 71: 1883-1891.

15. Sayan B, Kaya H (2016) Assessment of the environmental risk perceptions and environmental attitudes of nursing students. Contemp Nurse 52: 771-781.

16. Çelik S, Başaran T, Gökalp MR, Yeşildal M, Han O (2016) Hemşirelik ve tip öğrencilerinin çevre sorunlarina yönelik tutumlari. HSP 3: 91-98.

17. Ulas Kadioglu B, Uncu F (2018) Health sciences students' attitudes towards environmental problems. Journal of Current Researches on Health Sector 8: 285-296.

18. Bradley JC, Waliczek TM, Zajicek JM (1999) Relationship between environmental knowledge and environmental attitude of high school students. Journal of Environmental Education 30: 17-21.

19. Özmen D, Çetinkaya AC, Nehir S (2005) Üniversite öğrencilerinin çevre sorunlarina yönelik tutumlari. TSK Koruyucu Hekimlik Bülteni 4: 330-344.

20. Karakuş N, Selim S, Ardahanlioğlu ZR, Özer Ö, Çinar I (2016) Önlisans öğrencilerinin çevre ve doğa korumaya yönelik görüşlerinin değerlendirilmesi. International Journal of Human Sciences 13: 4058-4071.

21. Çinar N, Akduran F, Dede C, Altinkaynak S (2010) Hemşirelik Bölümü Son Sinif Öğrencilerinin Çevre Sorunlarina Yönelik Tutumlari. Maltepe Üniversitesi Hemşirelik Bilim ve Sanati Dergisi 242-252.

22. Erten S, Aydoğdu C (2011) Türkiyeli ve azerbeycanli öğrencilerde, ekosentrik, antroposentrik ve çevreye karşi antipatik tutum anlayişlari. Hacettepe University Journal of Education 41: 158-169.

23. Önder R (2015) İlköğretim öğrencilerinin çevre tutumlarinin incelenmesi. Karabük Üniversitesi Sosyal Bilimler Enstitüsü Dergisi 5: 115-124.

24. Demirel M, Gürbüz B, Karaküçük B (2009) Rekreasyonel aktivitelere katilimin çevreye yönelik tutum üzerindeki etkisi ve yeni ekolojik paradigma ölçeği'nin geçerliği ve güvenirliği. SPORMETRE Beden Eğitimi ve Spor Bilimleri Dergisi VII: 47-50.

25. Levine DS, Strube MJ (2012) Environmental attitudes, knowledge, intentions and behaviors among college students. J Soc Psychol 152: 308-326.

26. Lieflander AK, Bogner FX (2014) The effects of children's age and sex on acquiring proenvironmental attitudes through environmental education. J Environ Educ 45: 105-117.

27. Sam N, Gürsakal S, Sam R (2010) Üniversite öğrencilerinin çevresel risk algisi ve çevresel tutumlarinin belirlenmesi. Akademik Bakiş Dergisi 20: 1-16.

28. Bodur G, Taşocak G (2013) Nursing students' views about environmental sensitivity in Turkey. International Journal of Human Sciences 10: 820-831.

29. Duman Yüksel U, Özkazanç S (2015) Investigation of the environmental attitudes and approaches of university students. Procedia - Social and Behavioral Sciences 197: 2191-2200. 
30. Tikka PM, Kuitunen MT, Tynys SM (2000) Effects of educational background on students' attitudes, activity levels, and knowledge concerning the environment. The Journal of Environmental Education 31: 12-19.

31. Tindall DB, Davies S, Mauboules C (2003) Activism and conservation behavior in an environmental movement: The contradictory effects of gender. Society \& Natural Resources 16: 909-932.

32. Ünver S, Avcibaşi iM, Kizilcik Özkan Z (2015) Üniversite hastanesinde çalişan hemşirelerin çevre tutumu ve farkindalik düzeylerinin belirlenmesi. Anadolu Hemşirelik ve Sağlik Bilimleri Dergisi 18: 282-286.
33. Ozturk S, Enez K (2015) Determination of the perceptions of secondary education students towards environment and nature. J Environ Prot Ecol 16: 723-732.

34. Kanbak A (2015) Üniversite öğrencilerinin çevresel tutum ve davranişlari: Farkli değişkenler açisindan Kocaeli Üniversitesi örneği. Kocaeli Üniversitesi Sosyal Bilimler Dergisi 30: 77-90.

35. Beser A, Bahar Z, Arkan G, Cal A, Yesiltepe A (2017) Examination of nursing students' attitudes towards environmental problems. Progress in Health Sciences 7: 137-144. 